DOI: https://doi.org/10.24127/ajpm.v9i4.2945

\title{
PENGARUH MODEL KOOPERATIF TIPE NUMBERED HEADS TOGETHER PADA KEMAMPUAN KOMUNIKASI MATEMATIS SISWA
}

\author{
I Made Arnawa ${ }^{1}$, Liza Wulandari² \\ ${ }^{1}$ Universitas Andalas, Padang, Indonesia \\ ${ }^{2}$ Universitas Negeri Padang, Padang, Indonesia \\ E-mail: arnawa1963@ gmail.com ${ }^{1)}$ \\ $\underline{\text { lizawulndarii81@gmail.com }}^{2)}$
}

Received 16 July 2020; Received in revised form 10 November 2020; Accepted 27 December 2020

\begin{abstract}
Abstrak
Penelitian ini bertujuan mendeskripsikan ada atau tidaknya perbedaan kemampuan komunikasi matematis (KKM) antara siswa yang diajar menggunakan model pembelajaran kooperatif tipe Numbered Heads Together (NHT) dengan siswa yang diajar menggunakan model pembelajaran konvensional ditinjau dari tingkat kemampuan awal siswa yaitu tinggi, sedang, dan rendah pada siswa Kelas VIII SMP Negeri di Kota Pekanbaru. Jenis penelitian ini adalah eksperimen semu dengan rancangan posttest-only control group design. Jumlah sampel sebanyak 125 orang diambil secara acak dan bertingkat masing-masing 61 siswa dari sekolah percontohan dan 64 siswa dari sekolah non percontohan. Instrumen utama yang digunakan dalam penelitian ini adalah dua tes KKM yaitu tes KKM1 dan tes KKM2, kedua tes telah melalui proses validasi dan ujicoba dengan koefisien reliabilitas masing-masing 0,67 dan 0,66. Uji Mann-Witney digunakan untuk menganalisis ada atau tidaknya perbedaan rata-rata KKM antar kelas eksperimen dengan kelas kontrol pada masing-masing tingkat kemampuan awal siswa dan ANAVA 2 arah digunakan untuk menganalisis ada atau tidaknya interaksi antara faktor model pembelajaran dengan faktor kemampuan awal. Hasil penelitian ini menunjukkan bahwa: (1) KKM siswa pada kelas eksperimen lebih tinggi secara signifikan jika dibandingkan dengan siswa pada kelas kontrol; (2) Pada siswa dengan tingkat pengetahuan awal tinggi dan sedang, KKM siswa kelas eksperimen lebih tinggi secara signifikan jika dibandingkan dengan siswa pada kelas kontrol; (3) tidak terdapat interaksi antara faktor model pembelajaran dengan faktor kemampuan awal terhadap kemampuan komunikasi matematis.
\end{abstract}

Kata kunci: eksperimen semu; kemampuan awal; kemampuan komunikasi matematis; NHT

\begin{abstract}
This research aims to determine if there are any differences in mathematical communication skills between students taught using Numbered Heads Together (NHT) cooperative learning model with students who are taught using conventional learning models are reviewed by the students' prior knowledge (high, moderate, and low) in class VIII of SMP Negeri in Pekanbaru City. This type of research is quasi-experimentation with posttest-only control group design. Number of samples as much as 125 students taken randomly and stratified respectively 61 students from excelent school and 64 students from non excelent school. The main instruments used is a mathematical communication skill (CCS) i.e.CCS1 and CCS2 test, both tests have been through the process of validation and testing with reliability coefficients respectively 0.67 and 0.66. The Mann-Witney test is used to see if there is an average difference in CCS between experiments and control class at each the prior knowledge levels and the 2-way ANAVA is used to see if there the interaction between learning model variables and the prior knowledge variables. The results of this study showed that: (1) Students' CCS in the experimental class are significantly higher when compared to students in the control class; (2) Students' CCS in the experimental class are significantly higher when compared to students in the control class either at the high or moderate prior knowledge levels; (3) There is no interaction between the learning model and the prior knowledge toward CCS.
\end{abstract}

Keywords: Mathematical communication skills; NHT; prior knowledge; quasi-experimentation

This is an open access article under the Creative Commons Attribution 4.0 International License 
DOI: https://doi.org/10.24127/ajpm.v9i4.2945

\section{PENDAHULUAN}

Kemampuan matematika siswa Indonesia pada semua tingkat pendidikan, mulai dari sekolah dasar sampai perguruan tinggi masih jauh dari yang diharapkan (Yuwandra dan Arnawa, 2020; Syafriafdi, Fauzan, Arnawa, Anwar, \& Widada, 2019; Ismail, Arnawa, \& Yerizon, 2020; Rahmi, Arnawa, \& Yerizon, 2019; Roza, Arnawa, \& Yerizon, 2018; Arnawa, Yerizon, \& Nita, 2019). Salah satu faktor yang diduga sebagai penyebabnya, baik di SD, SMP, maupun SMA adalah metode mengajar yang digunakan guru belum mampu mengembangkan potensi yang dimiliki siswa. Hal ini berakibat pada: (1) lemahnya kemampuan pemahaman konsep dan pemecahan masalah matematis siswa SD (Syafriafdi dkk, 2019; Yuwandra dkk, 2020); (2) lemahnya kemampuan matematis siswa SMP yaitu kemampuan pemecahan masalah matematis (Rahmi dkk, 2019) dan kemampuan komunikasi matematis (Ismail dkk, 2020); (3) lemahnya kemampuan komunikasi matematis siswa SMA (Roza dkk, 2018); (4) lemahnya kemampuan pembuktian matematis mahasiswa (Arnawa dkk, 2019). Hal ini sejalan dengan hasil studi yang dilakukan oleh Trend In International Mathematics and Science Study (TIMSS) pada tahun 1995, 1999 , 2003, 2007, 2011, 2015 dan hasil studi yang dilakukan oleh Programme for International Student Assessment (PISA) pada tahun 2000, 2003, 2006,2009, 2012, 2015, 2018 yaitu bahwa rata-rata skor siswa Indonesia baik untuk TIMMS maupun PISA selalu dibawah rata-rata Internasional (Rusdi, Fauzan, Arnawa, \& Lufri, 2020).

Salah satu kemampuan matematis yang paling bermasalah pada siswa SMP Negeri Kota Pekanbaru adalah kemampuan komunikasi matematis.
Berdasarkan hasil observasi yang dilakukan pada tanggal 26 Maret 2019 terhadap 32 siswa SMP Negeri Kota Pekanbaru yaitu dengan memberikan 3 soal essai sesuai indikator kemampuan komunikasi diperoleh bahwa hanya 8 dari 32 orang siswa yang menjawab dengan benar. Dari hasil jawaban siswa terlihat bahwa sebagian besar siswa mengalami kesulitan dalam mengkomunikasikan ide atau gagasannya melalui simbol, tabel, diagram, dan sebagainya untuk memperjelas sifat atau masalah matematika yang dipelajari siswa.

Model pembelajaran kooperatif tipe NHT merupakan salah satu model pembelajaran yang dapat digunakan untuk meningkatkan kemampuan komunikasi matematis siswa (Lagur, Makur, \& Ramda, 2018; Adesty., Nurhanurawati, \& Widyastuti, 2014). Lagur dkk (2018) melakukan penelitian di SMK sedangkan Adesty dkk (2014) melakukan penelitian di SMP, hasil penelitian mereka mengungkapkan bahwa kemampuan komunikasi matematis siswa yang diajar menggunakan model kooperatif tipe NHT lebih tinggi secara signifikan jika dibandingkan dengan siswa yang diajar secara konvensional.

Selain faktor model pembelajaran, dalam hal ini model pembelajaran kooperatif tipe NHT, kemampuan awal merupakan salah satu faktor yang turut menentukan keberhasilan siswa dalam belajar matematika (Hailikari, Nevgi, \& Komulainen, 2008; Kiwanuka, Damme, Noortgate, Anumendem, \& Namusisi, 2015; Aminah, Kusumah, Suryadi, \& Sumarmo, 2018), oleh karena itu harus dijadikan pertimbangan dalam memilih suatu model pembelajaran, karena suatu model pembelajaran belum tentu cocok dengan semua kelompok kemampuan 
awal siswa. Penelitian ini bermaksud melengkapi penelitian yang telah dilakukan oleh Adesty dkk (2014) dan Lagur dkk (2018), yaitu untuk mengetahui apakah model pembelajaran kooperatif tipe NHT cocok untuk semua kelompok kemampuan awal siswa, baik untuk siswa yang kemampuan awal tinggi, sedang, maupun rendah?"

Tujuan utama penelitian ini adalah untuk mendeskripsikan pengaruh model pembelajaran kooperatif tipe NHT terhadap kemampuan komunikasi matematis siswa, baik untuk siswa kemampuan awal rendah, sedang, maupun tinggi. Dengan demikian, hipotesis utama penelitian ini adalah: (1) Kemampuan komunikasi matematis siswa yang belajar menggunakan model kooperatif tipe NHT lebih tinggi secara signifikan dari siswa yang belajar secara konvensional, baik untuk siswa kemampuan awal rendah, sedang, maupun tinggi; (2) Terdapat interaksi yang signifikan antara faktor model pembelajaran dengan faktor kemampuan awal.

\section{METODE PENELITIAN}

Jenis penelitian ini adalah eksperimen semu dengan rancangan posttest-only control group design seperti dinyatakan pada Tabel 1.

Tabel 1. Rancangan Penelitian

\begin{tabular}{ccc}
\hline Kelompok & Perlakuan & Posttest \\
\hline Eksperimen & $\mathrm{X}$ & $\mathrm{O}$ \\
\hline Kontrol & - & $\mathrm{O}$ \\
\hline
\end{tabular}

Populasi penelitian ini adalah seluruh siswa kelas VIII SMP Negeri Kota Pekanbaru (10 SMP Negeri percontohan dan 30 SMP Negeri non percontohan), jumlah sampel sebanyak 125 orang diambil secara acak dan bertingkat masing-masing 61 siswa dari sekolah percontohan dan 64 siswa dari sekolah non percontohan.

Instrumen yang digunakan dalam penelitian ini terdiri dari tes kemampuan awal (KA) yang terdiri dari 5 soal yang disusun berdasarkan materi prasyarat mata pelajaran matematika untuk topik lingkaran dan tes kemampuan komunikasi matematis (KKM) yang terdiri dari KKM1 dan KKM2 yang disusun berdasarkan indikator kemampuan komunikasi matematis dan materi pembelajaran matematika yaitu sifat-sifat lingkaran dan persamaan garis singgung lingkaran yang masing-masing terdiri dari 3 buah soal. Setiap soal diberi skor $0,1,2$, atau 3 sesuai dengan kelengkapan jawaban siswa. Sebelum digunakan dalam penelitian, tes KA dan KKM beserta rubrik penilaiannya telah divalidasi oleh pakar pendidikan matematika dari Universitas Negeri Padang dan telah dinyatakan valid. Selanjutnya, tes KA dan KKM diujicoba untuk mengetahui validitas butir, daya pembeda, tingkat kesukaran, dan reliabitas tes. Hasil ujicoba menunjukkan bahwa tes KA dan KKM sudah memenuhi kriteria soal yang baik dengan koefisien reliabilitas 0,672 untuk tes KA, 0,670 untuk KKM1, dan 0,660 untuk KKM2. Berdasarkan skor tes KA, setiap siswa dikelompokkan kedalam salah satu kemampuan awal tinggi, sedang, atau rendah dengan melihat posisi nilai siswa (x) dari rata-rata $(\bar{x})$ dan standar deviasi (SD) sebagai berikut. (1) tinggi, jika $x \geq \bar{x}+S D$, (2) sedang, jika $\bar{x}-S D \leq x \leq \bar{x}+S D$, dan (3) rendah, jika $x \leq \bar{x}-S D$ (Arikunto, 2012). Berdasarkan hasil perhitungan, banyaknya siswa yang tergolong kedalam kemampuan awal tinggi, sedang, atau rendah masing-masing adalah 16, 31, dan 14 untuk kelas eksperimen dan 20, 27, dan 17 untuk kelas kontrol. 
DOI: https://doi.org/10.24127/ajpm.v9i4.2945

Pembelajaran pada kelas
eksperimen menggunakan model
kooperatif tipe NHT, secara garis
besarnya, tahapan kegiatannya sebagai
berikut. (1) Guru mempersiapkan RPP
dan LKS, (2) Guru membentuk kelompok heterogen yang terdiri dari 35 orang siswa dan memberi nomor yang berbeda untuk setiap anggota kelompok, (3) Guru membimbing siswa berdiskusi dalam masing-masing kelompoknya untuk menyelesaikan permasalahan yang ada pada LKS, (4) Guru memanggil satu nomor, kemudian siswa yang nomornya dipanggil maju ke depan kelas mempresentasikan hasil diskusi kelompoknya, (5) Guru bersama siswa membuat kesimpulan tentang hasil presentasi tersebut. Sementara itu, pembelajaran pada kelas kontrol menggunakan model konvensional, secara garis besarnya, tahapan kegiatannya sebagai berikut. (1) Guru menyampaikan materi pembelajaran sesuai dengan silabus, (2) Guru memberi kesempatan kepada siswa untuk bertanya jika ada hal-hal yang dianggap kurang jelas, (3) Guru memberikan latihan/pekerjaan rumah.

Kegiatan pembelajaran pada kelas eksperimen dan kontrol dilaksanakan selaman 10 kali pertemuan (11 Februari -14 Maret 2020), 6 kali pertemuan untuk materi konsep-konsep dan sifat-sifat lingkaran dan 4 kali pertemuan untuk materi persamaan garis singgung lingkaran. Setelah pertemuan ke 4 dan dan setelah pertemuan ke 10, masingmasing dilaksanakan tes KKM1 dan tes KKM2 pada kedua kelas.

Untuk menjawab pertanyaan penelitian nomor satu, langkah-langkah yang dilakukan sebagai berikut. (1) Melakukan uji normalitas terhadap skor tes KKM1, KKM2, dan gabungan skor tes KKM1 dan KKM2 untuk masingmasing kelompok kemamupan awal (tinggi, sedang, rendah) dan pada masing-masing kelas, baik kelas eksperimen maupun kelas kontrol, (2) Melakukan uji homogenitas varian untuk masing-masing kelompok data yang akan dibandingkan, (3) jika kelompok data yang akan dibandingkan normal dan homogen, selanjutnya dilakukan uji t, (4) jika kelompok data yang dibandingkan normal tetapi tidak homogen, selnjutnya dilakukan uji t', (5) jika kelompok data yang dibandingkan ada yang tidak normal, selanjutnya dilakukan uji MannWitney. Untuk menjawab pertanyaan penelitian nomor dua, analisis dilakukan terhadap data skor gabungan tes KKM1 dan KKM2 menggunakan uji ANAVA 2 arah dengan terlebih dahulu melakukan uji persayaratan analisis yaitu uji normalitas atau diasumsikan normal (jika jumlah datanya lebih dari 30) dan uji kesamaan varian antara kelas eksperimen dan kelas kontrol dengan Uji Levene. Untuk menjawab pertanyaan penelitian nomor tiga yaitu untuk mengetahui kelompok kemampuan awal mana yang paling diuntungkan oleh pembelajaran berdasarkan model kooperatif tipe NHT digunakan diagram interaksi. Kelompok kemampuan awal yang selisih rata-rata kemampuan komunikasi matematisnya tertinggi antara kelas eksperimen dengan kelas kontrol merupakan kelompok yang paling diuntungkan. Pengujian hipotesis persyaratan analisis dilakukan pada taraf nyata $10 \%$ sedangkan pengujian hipotsis tentang ada tidaknya perbedaan rata-rata dan ada tidaknya interaksi dilakukan pada taraf nyata $5 \%$. Semua perhitungan dikerjakan dengan bantuan SPSS 21.

\section{HASIL DAN PEMBAHASAN}

Gambaran tentang hasil pengujian terhadap hipotesis 1 dapat dilihat dari sajian data hasil penelitian dalam bentuk nilai maksimum (Max), 
DOI: $\underline{\text { https://doi.org/10.24127/ajpm.v9i4.2945 }}$

nilai minimum (Min), nilai ideal, ratarata $(\bar{x})$, standar deviasi (SD), dan jumlah siswa (N) pada masing-masing kelompok kemampuan awal siswa yaitu: tinggi, sedang, dan rendah seperti dinyatakan dalam Tabel 2, 3, dan 4 .

Tabel 2. Data skor tes KKM1 siswa per kemampuan awal

\begin{tabular}{ccccccc}
\hline Karakteristik & \multicolumn{6}{c}{ Kemampuan Awal } \\
\cline { 2 - 7 } Data & \multicolumn{2}{c}{ Tinggi } & \multicolumn{2}{c}{ Sedang } & \multicolumn{2}{c}{ Rendah } \\
\cline { 2 - 7 } & Eksperimen & Kontrol & Eksperimen & Kontrol & Eksperimen & Kontrol \\
\hline N & 16 & 20 & 31 & 27 & 14 & 17 \\
Nilai Max & 9 & 8 & 8 & 7 & 6 & 6 \\
Nilai Min & 4 & 4 & 4 & 3 & 2 & 2 \\
Nilai Ideal & 9 & 9 & 9 & 9 & 9 & 9 \\
$\bar{X}$ & 6,81 & 6,2 & 5,62 & 5,22 & 3,71 & 3,23 \\
SD & 1,42 & 1,19 & 0,97 & 1,28 & 1,13 & 1,25 \\
\hline
\end{tabular}

Tabel 3. Data skor tes KKM2 siswa per kemampuan awal

\begin{tabular}{ccccccc}
\hline Karakteristik & \multicolumn{6}{c}{ Kemampuan Awal } \\
\cline { 2 - 7 } Data & \multicolumn{2}{c}{ Tinggi } & \multicolumn{2}{c}{ Sedang } & \multicolumn{2}{c}{ Rendah } \\
\cline { 2 - 7 } & Eksperimen & Kontrol & Eksperimen & Kontrol & Eksperimen & Kontrol \\
\hline N & 16 & 20 & 31 & 27 & 14 & 17 \\
Nilai Max & 9 & 9 & 9 & 8 & 7 & 7 \\
Nilai Min & 6 & 4 & 6 & 3 & 3 & 2 \\
Nilai Ideal & 9 & 9 & 9 & 9 & 9 & 9 \\
$\bar{X}$ & 7,87 & 6,6 & 6,83 & 5,70 & 4,64 & 3,82 \\
SD & 1,2 & 1,31 & 1,09 & 1,40 & 1,21 & 1,28 \\
\hline
\end{tabular}

Tabel 4. Data Skor Gabungan Tes KKM1 dan KKM2 siswa per kemampuan awal

\begin{tabular}{ccccccc}
\hline Karakteristik & \multicolumn{6}{c}{ Kemampuan Awal } \\
\cline { 2 - 7 } Data & \multicolumn{2}{c}{ Tinggi } & \multicolumn{2}{c}{ Sedang } & \multicolumn{2}{c}{ Rendah } \\
\cline { 2 - 7 } & Eksperimen & Kontrol & Eksperimen & Kontrol & Eksperimen & Kontrol \\
\hline N & 16 & 20 & 31 & 27 & 14 & 17 \\
Nilai Max & 18 & 15 & 14 & 14 & 9 & 8 \\
Nilai Min & 10 & 8 & 6 & 6 & 5 & 5 \\
Nilai Ideal & 18 & 18 & 18 & 18 & 18 & 18 \\
$\bar{X}$ & 14,68 & 12,80 & 10,92 & 9,51 & 7,64 & 6,04 \\
SD & 2,49 & 2,30 & 2,20 & 2,51 & 1,23 & 2,35 \\
\hline
\end{tabular}

Dari Tabel 2, 3, dan 4 terlihat bahwa rata-rata kemampuan komunikasi matematis siswa, baik untuk kemampuan awal tinggi, sedang, maupun rendah pada kelas eksperimen lebih tinggi secara konsisten jika dibandingkan dengan kelas kontrol. Selanjutnya, untuk mengetahui apakah perbedaan-perbedaan tersebut berbeda secara signifikan, dilakukan uji perbedaan rata-rata dengan terlebih dahulu melakukan uji normalitas dengan Uji Kolmogorov-Smirnov terhadap semua kelompok data yang dibandingkan. Hasil uji normalitas dinyatakan pada Tabel 5, 6, dan 7 . 
DOI: https://doi.org/10.24127/ajpm.v9i4.2945

Tabel 5. Hasil uji normalitas data skor tes KKM1 siswa per kemampuan awal dengan uji Kolmogorov-Smirnov.

\begin{tabular}{ccccccc}
\hline Parameter & \multicolumn{6}{c}{ Kemampuan Awal } \\
\cline { 2 - 7 } Kolmogorov- & \multicolumn{2}{c}{ Tinggi } & \multicolumn{2}{c}{ Sedang } & \multicolumn{2}{c}{ Rendah } \\
\cline { 2 - 7 } Smirnov & Eksperimen & Kontrol & Eksperimen & Kontrol & Eksperimen & Kontrol \\
\hline N & 16 & 20 & 31 & 27 & 14 & 17 \\
Statistik Uji & 0.177 & 0.184 & 0,207 & 0,163 & 0,187 & 0,222 \\
df & 16 & 17 & 31 & 27 & 14 & 17 \\
Sig. & 0.191 & 0.076 & 0,011 & 0,015 & 0,200 & 0,026 \\
Keputusan & Normal & Tidak & Tidak & Tidak & Normal & Tidak \\
& & normal & normal & normal & & normal \\
\hline
\end{tabular}

Tabel 6. Hasil uji normalitas data skor tes KKM2 Siswa per kemampuan awal dengan uji Kolmogorov-Smirnov.

\begin{tabular}{ccccccc}
\hline Parameter & \multicolumn{6}{c}{ Kemampuan Awal } \\
\cline { 2 - 7 } Kolmogorov- & \multicolumn{2}{c}{ Tinggi } & \multicolumn{2}{c}{ Sedang } & \multicolumn{2}{c}{ Rendah } \\
\cline { 2 - 7 } Smirnov & Eksperimen & Kontrol & Eksperimen & Kontrol & Eksperimen & Kontrol \\
\hline N & 16 & 20 & 31 & 27 & 14 & 17 \\
Statistik Uji & 0,262 & 0,220 & 0,177 & 0,229 & 0,187 & 0,268 \\
df & 16 & 20 & 31 & 27 & 14 & 17 \\
Sig. & 0,004 & 0,012 & 0,014 & 0,001 & 0,200 & 0,002 \\
Keputusan & Tidak & Tidak & Tidak & Tidak & Normal & Tidak \\
& normal & normal & normal & normal & & normal \\
\hline
\end{tabular}

Tabel 7. Hasil uji normalitas data skor gabungan tes KKM1 dan KKM2 siswa per kemampuan awal dengan uji Kolmogorov-Smirnov.

\begin{tabular}{ccccccc}
\hline Parameter & \multicolumn{6}{c}{ Kemampuan Awal } \\
\cline { 2 - 7 } Kolmogorov- & \multicolumn{2}{c}{ Tinggi } & \multicolumn{2}{c}{ Sedang } & \multicolumn{2}{c}{ Rendah } \\
\cline { 2 - 7 } Smirnov & Eksperimen & Kontrol & Eksperimen & Kontrol & Eksperimen & Kontrol \\
\hline N & 16 & 20 & 31 & 27 & 14 & 17 \\
Statistik Uji & 0,172 & 0,230 & 0,206 & 0,184 & 0,260 & 0,262 \\
df & 16 & 20 & 31 & 27 & 14 & 17 \\
Sig. & 0,002 & 0,007 & 0,002 & 0,019 & 0,011 & 0,003 \\
Keputusan & Tidak & Tidak & Tidak & Tidak & Tidak & Tidak \\
& normal & normal & normal & normal & normal & normal \\
\hline
\end{tabular}

Dari Tabel 5, 6, dan 7 terlihat bahwa pasangan data yang akan dibandingkan rata-ratanya, tidak keduanya berdistribusi normal, sehingga tidak perlu lagi melakukan uji homogenitas varian. Dengan demikian, uji perbedaan rata-rata yang digunakan adalah uji non parametrik dengan subjek yang saling bebas yaitu Uji MannWitney dengan hasil seperti yang disajikan pada Tabel 8, 9, dan 10.
Dari Tabel 8, 9, dan 10 terlihat bahwa rata-rata kemampuan komunikasi matematis siswa dengan kemampuan awal tinggi dan sedang pada kelas eksperimen berbeda (lebih tinggi) secara signifikan jika dibandingkan dengan kelas kontrol, namun perbedaan tersebut tidak signifikan pada siswa dengan kemampuan awal rendah. 
DOI: https://doi.org/10.24127/ajpm.v9i4.2945

Tabel 8. Hasil uji perbedaan rata-rata skor tes KKM1 siswa per kemampuan awal antara kelas eksperimen dan kontrol dengan Uji Mann-Witney.

\begin{tabular}{|c|c|c|c|c|c|c|}
\hline \multirow{3}{*}{$\begin{array}{c}\text { Parameter } \\
\text { Uji } \\
\text { Mann-Witney }\end{array}$} & \multicolumn{6}{|c|}{ Kemampuan Awal } \\
\hline & \multicolumn{2}{|c|}{ Tinggi } & \multicolumn{2}{|c|}{ Sedang } & \multicolumn{2}{|c|}{ Rendah } \\
\hline & Eksperimen & Kontrol & Eksperimen & Kontrol & Eksperimen & Kontrol \\
\hline $\mathrm{N}$ & 16 & 20 & 31 & 27 & 14 & 17 \\
\hline Statistik U & \multicolumn{2}{|c|}{118,500} & \multicolumn{2}{|c|}{332,500} & \multicolumn{2}{|c|}{89.000} \\
\hline Sig. & \multicolumn{2}{|c|}{0,175} & \multicolumn{2}{|c|}{0,166} & \multicolumn{2}{|c|}{0,219} \\
\hline Keputusan & \multicolumn{2}{|c|}{$\begin{array}{c}\text { Tidak Berbeda } \\
\text { signifikan }\end{array}$} & \multicolumn{2}{|c|}{$\begin{array}{c}\text { Tidak Berbeda } \\
\text { signifikan }\end{array}$} & \multicolumn{2}{|c|}{$\begin{array}{l}\text { Tidak Berbeda } \\
\text { signifikan }\end{array}$} \\
\hline
\end{tabular}

Tabel 9. Hasil uji perbedaan rata-rata skor tes KKM2 Siswa per kemampuan awal antara kelas eksperimen dan kontrol dengan Uji Mann-Witney.

\begin{tabular}{|c|c|c|c|c|c|c|}
\hline \multirow{3}{*}{$\begin{array}{c}\text { Parameter } \\
\text { Uji } \\
\text { Mann-Witney }\end{array}$} & \multicolumn{6}{|c|}{ Kemampuan Awal } \\
\hline & \multicolumn{2}{|c|}{ Tinggi } & \multicolumn{2}{|c|}{ Sedang } & \multicolumn{2}{|c|}{ Rendah } \\
\hline & Eksperimen & Kontrol & Eksperimen & Kontrol & Eksperimen & Kontrol \\
\hline $\mathrm{N}$ & 16 & 20 & 31 & 27 & 14 & 17 \\
\hline Statistik U & \multicolumn{2}{|c|}{78,500} & \multicolumn{2}{|c|}{234,500} & \multicolumn{2}{|c|}{72,500} \\
\hline Sig. & \multicolumn{2}{|c|}{0,008} & \multicolumn{2}{|c|}{0,003} & \multicolumn{2}{|c|}{0,056} \\
\hline Keputusan & \multicolumn{2}{|c|}{ Berbeda signifikan } & \multicolumn{2}{|c|}{ Berbeda signifikan } & \multicolumn{2}{|c|}{ Tidak berbeda signifikan } \\
\hline
\end{tabular}

Tabel 10. Hasil uji perbedaan rata-rata skor gabungan tes KKM1 dan KKM2 siswa per kemampuan awal antara kelas eksperimen dan kontrol dengan uji Mann-Witney.

\begin{tabular}{|c|c|c|c|c|c|c|}
\hline \multirow{3}{*}{$\begin{array}{l}\text { Parameter Uji } \\
\text { Mann-Witney }\end{array}$} & \multicolumn{6}{|c|}{ Kemampuan Awal } \\
\hline & \multicolumn{2}{|c|}{ Tinggi } & \multicolumn{2}{|c|}{ Sedang } & \multicolumn{2}{|c|}{ Rendah } \\
\hline & Eksperimen & Kontrol & Eksperimen & Kontrol & Eksperimen & Kontrol \\
\hline $\mathrm{N}$ & 16 & 20 & 31 & 27 & 14 & 17 \\
\hline Statistik U & \multicolumn{2}{|c|}{94.000} & \multicolumn{2}{|c|}{278,500} & \multicolumn{2}{|c|}{98.000} \\
\hline Sig. & \multicolumn{2}{|c|}{0,033} & \multicolumn{2}{|c|}{0,028} & \multicolumn{2}{|c|}{0,388} \\
\hline Keputusan & \multicolumn{2}{|c|}{ Berbeda signifikan } & \multicolumn{2}{|c|}{ Berbeda signifikan } & \multicolumn{2}{|c|}{$\begin{array}{l}\text { Tidak berbeda } \\
\text { signifikan }\end{array}$} \\
\hline
\end{tabular}

Untuk menguji hipotesis 2, analisis dilakukan terhadap data skor gabungan tes KKM1 dan KKM2 menggunakan ANAVA 2 arah. Karena jumlah data pada kelas eksperimen 61 dan kelas kontrol 64 masing-masing lebih dari 30, maka dapat diasumsikan bahwa kedua kelompok data tersebut berdistribusi normal, selanjutnya dengan menggunakan Uji Levene untuk uji homogenitas varian diperoleh nilai statistik uji $=1,406$ dengan nilai sig. $=$ 0,238 , sehingga dapat disimpulkan kedua kelompok data tersebut homogen. Karena sudah memenuhi uji persyaratan analisis, maka uji ANAVA 2 arah dapat dilaksanakan dan hasilnya dinyatakan dalam Tabel 11.

Dari Tabel 11 tersebut terungkap bahwa: (1) tidak terdapat interaksi yang signifikan antara faktor model pembelajaran dengan faktor kemampuan awal, (2) kemampuan komunikasi matematis kelas eksperimen berbeda secara signifikan jika dibandingkan dengan kelas kontrol, dan (3) Ada perbedaan kemampuan komunikasi matematis yang signifikan antara ketiga kemampuan awal tinggi, sedang, maupun rendah. 
DOI: https://doi.org/10.24127/ajpm.v9i4.2945

Tabel 11. Hasil uji ANAVA 2 arah terhadap skor gabungan tes KKM1 dan KKM2 Siswa.

\begin{tabular}{cccccc}
\hline Sumber & $\begin{array}{c}\text { Jumlah } \\
\text { Kuadrat }\end{array}$ & df & $\begin{array}{c}\text { Rataan } \\
\text { Kuadrat }\end{array}$ & F & Sig. \\
Model & 73,099 & 1 & 73,099 & 14,159 & 0,000 \\
K. Awal & 618,795 & 2 & 309,398 & 59.927 & 0,000 \\
Model * K. awal & 1,435 & 2 & 0,717 & 0,139 & 0,870 \\
\hline
\end{tabular}

Gambaran tentang kelompok kemampuan awal mana yang lebih diuntungkan oleh model pembelajaran kooperatif tipe NHT dapat dilihat dari diagram interaksi antara faktor model pembelajaran (NHT dan Konvesional) dengan kemampuan awal (tinggi, sedang, rendah) seperti yang dinyatakan pada Gambar 1. Dari Gambar 1 terlihat bahwa selisih rata-rata kemampuan komunikasi matematis dari yang paling besar sampai paling kecil antara kelas eksperimen dan kelas kontrol berturutturut terjadi pada kelompok kemampuan awal tinggi, sedang, dan rendah. Ini berarati, kelompok kemampuan awal tinggi paling diuntungkan (memperoleh manfaat) yang paling maksimal dari kegiatan pembelajaran yang berdasarkan model kooperatif tipe NHT.

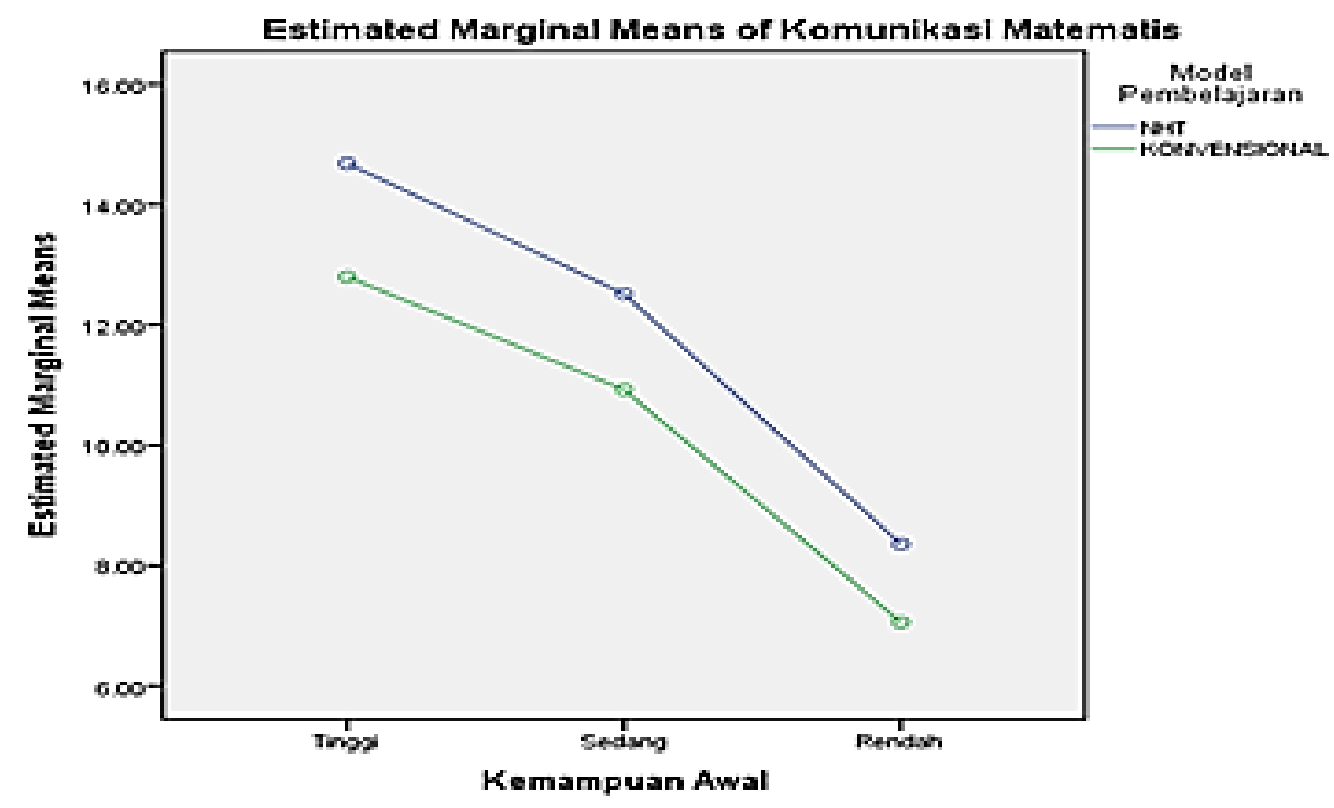

Gambar 1. Diagram interaksi model pembelajaran dengan kemampuan awal.

Mengapa rata-rata kemampuan komunikasi matematis siswa kelas eksperimen lebih tinggi secara signifikan jika dibandingkan dengan kelas kontrol? Hasil penelitian ini menunjukkan bahwa aktivitas diskusi kelompok berdampak positif terhadap kemampuan matematika siswa. Melalui diskusi kelompok, siswa yang belum memahami tugas yang diberikan guru dapat bertanya kepada anggota kelompok lainnya. Karena setiap anggota kelompok mempunyai tanggungjawab yang sama terhadap kesuksesan kelompok, maka siswa yang sudah paham (umumnya siswa dengan kemampuan awal tinngi) dengan senang hati akan mengajari atau berperan sebagai tutor sebaya bagi anggota kelompok lainnya. Siswa yang berperan sebagai tutor sebaya, disamping 
memenuhi tanggungjawab sebagai anggota kelompok yang baik, siswa tersebut juga akan memperoleh manfaat dari kegiatan tersebut yaitu dapat meningkatkan ketrampilannya dalam bermatematika melalui pertanyaanpertanyaan yang tak terduga dari anggota kelompok. Dalam pembelajaran kooperatif tipe NHT, siswa yang mewakili suatu kelompok dalam mempresentasikan hasil diskusinya di depan kelas ditentukan secara acak oleh guru berdasarkan nomor kepala yang dimiliki siswa, tujuannya agar setiap anggota kelompok mempersiapkan diri sebaik-baiknya dalam memahami tugas yang diberikan guru. Hal ini yang menyebabkan setiap siswa berusaha semaksimal mungkin untuk mengembangkan kemampuan matematikanya. Hasil penelitian ini mempertegas apa yang sudah ditemukan oleh peneliti terdahulu (misalnya Leasa \& Corebima, 2017; Mauliza, 2020; Nursyamsi \& Corebima, ,2016; Adesty dkk, 2014; Lagur dkk, 2018) yaitu bahwa model pembelajaran kooperatif tipe NHT dapat meningkatkan hasil belajar. Mengapa rata-rata kemampuan komunikasi matematis siswa berkemampuan awal tinggi dan sedang kelas eksperimen lebih tinggi secara signifikan jika dibandingkan dengan kelas kontrol? tetapi tidak signifikan pada siswa dengan kemampuan awal rendah? Hasil penelitian yang disajikan pada Tabel 8, 9, dan 10 menunjukkan bahwa dibutuhkan penguasaan materi matematika tertentu yang memadai agar dapat terlibat secara aktif dan berhasil dalam diskusi kelompok. Bagi siswa dengan kemampuan awal rendah, diskusi kelompok sangat membantu mereka dalam memahami tugas matematika yang diberikan guru, tetapi tidak signifikan untuk dapat meningkatkan kemampuan mereka dalam bermatematika, walaupun mungkin sudah berulang-ulang dijelaskan oleh teman sejawatnya. Hasil penelitian ini sejalan dengan pendapat Hailikari dkk (2008), Kiwanuka dkk (2015), dan Aminah dkk (2018) yaitu bahwa pengetahuan awal adalah salah satu faktor yang menentukan keberhasilan seorang siswa dalam pembelajaran matematika, sedangkan media pembelajaran, model pembelajaran dan sebagainya hanya berperan sebagai penyokong agar seorang siswa dapat mencapai kemampuan maksimalnya.

Apa implikasi dari tidak adanya interaksi antara faktor model pembelajaran dengan faktor kemampuan awal? Idealnya seorang guru harus berusaha memilih model pembelajaran yang sesuai dengan karakteristik siswanya (kemampuan awal, motivasi belajar, jenis kelamin, dan sebagainya) yang pada umumnya beragam. Hasil penelitian ini menunjukkan bahwa guru boleh menerapkan model pembelajaran kooperatif tipe NHT tanpa perlu memperhatikan kemampuan awal siswa. Namun demikian, untuk model pembelajaran lainnya selain model kooperatif tipe NHT, guru harus berhatihati. Salah satu model menunjukkan adanya interaksi dengan kemampuan awal misalnya model pembelajaran pemecahan masalah (Muin, Novianti, \& Musyrifah, 2017). Ada beberapa model/strategi pembelajaran yang dapat digunakan dalam pembelajaran tanpa memeperhatikan kemampuan awal, misalnya connecting, organizing, reflecting, extending (CORE) dan group meta cognitive approach (GMCA), dan discovery learning tidak berinteraksi dengan kemampuan awal (Fauzi, 2015; Yumiati \& Kusumah, 2019; Sinambela $\mathrm{dkk}, 2018)$. 
DOI: https://doi.org/10.24127/ajpm.v9i4.2945

\section{KESIMPULAN DAN SARAN}

Berdasarkan hasil penelitian dan pembahasan yang telah dikemukan di atas dapat diambil kesimpulan dan saran sebagai berikut. (1) Kemampuan komunikasi matematis siswa SMP Negeri Kelas VIII Kota Pekanbaru yang belajar matematika berdasarkan model kooperatif tipe NHT lebih tinggi secara signifikan jika dibandingkan dengan yang belajar secara konvensional, (2) Kemampuan komunikasi matematis siswa SMP Negeri Kelas VIII Kota Pekanbaru yang berkemampuan awal tinggi dan sedang yang belajar matematika berdasarkan model kooperatif tipe NHT lebih tinggi secara signifikan jika dibandingkan dengan yang belajar secara konvensional, (3) Tidak terdapat interaksi antar faktor model pembelajaran dengan faktor kemampuan awal, (4) untuk penelitian lebih lanjut, disarankan menambahkan variabel moderator berupa level sekolah.

\section{DAFTAR PUSTAKA}

Adesty, M., Nurhanurawati, \& Widyastuti. (2014). Pengaruh Model Pembelajaran Kooperatif Tipe Nht Terhadap Kemampuan Komunikasi Matematis Dan Belief. Jurnal pendidikan matematika Universitas Lampung, 2(2).

Aminah, M., Kusumah, Y. S., Suryadi, D., \& Sumarmo, U. (2018). The effect of metacognitive teaching and mathematical prior knowledge on mathematical logical thinking ability and selfregulated learning. International Journal of Instruction, 11(3), 45 62.https://doi.org/10.12973/iji.2 $018.1134 \mathrm{a}$

Arikunto, S. (2012). Prosedur Penelitian Suatu Pendekatan Praktek. Jakarta: Rineka Cipta.
Arnawa, I. M., Yerizon, \& Nita, S. (2019). Improvement Students' Level of Proof Ability in Abstract Algebra Through APOS Theory Approach. International Journal of Science and Technology Research, 8(7), 128131.

Fauzi, M.A. (2015). The enhancement of student's Mathematical connection ability and selfregulation learning with metacognitive learning approach in Junior High School. International Conference on Research and Education in Mathematics (ICREM7), 174179 , doi: 10.1109/ICREM.2015.7357048.

Hailikari, T., Nevgi, A. \& Komulainen, E. (2008). Academic self-beliefs and prior knowledge as predictors of student achievement in Mathematics: a structural model, Educational Psychology, 28(1), 59-71. https://doi.org/10.1080/0144341 0701413753.

Ismail, R. N., Arnawa, I. M., \& Yerizon, Y. (2020). Student worksheet usage effectiveness based on realistics mathematics educations toward mathematical communication ability of junior high school student. Journal of Fhysic: Conference Series, 1554 012044

Kiwanuka, H. N., Damme, J.V, Noortgate, W.V.D, Anumendem, D.N., \& Namusisi, S. (2015). Factors affecting Mathematics achievement of first-year secondary school students in Central Uganda. South African Journal of Education, 35(3), 116.https://doi.org/10.15700/SAJ E.V35N3A1106. 
DOI: https://doi.org/10.24127/ajpm.v9i4.2945

Lagur, D. S., Makur, A. P., \& Ramda, A.H. (2018). Pengaruh Model Pembelajaran Kooperatif Tipe Numbered Head Together Terhadap Kemampuan Komunikasi Matematis. Mosharafa: Jurnal Pendidikan Matematika, 7(3), 357-368.

Leasa, M. \& Corebima, A. D. (2017). The effect of numbered heads together (NHT) cooperative learning model on the cognitive achievement of students with different academic ability. Journal of physic: Conference Series, 795012071.

Mauliza. (2020). Improving Students' Learning Result Using Numbered Heads Together Model. International Journal for Educational and Vocational Studies, 2(3), 301-303.

Muin, A., Novianti, L. \& Musyrifah, E. (2017). Analysis of mathematical reflective thinking skills based on learning model and mathematical prior knowledge. Advances in Social Science, Education and Humanities Research, 115, 2127.

Nursyamsi S.Y. \& Corebima, A.D. (2016). The effect of numbered heads together (NHT) learning strategy on the retention of senior high school students in Muara Badak, East Kalimantan, Indonesia. European Journal of Education Studies, 2(5), pp. 4758.
Rahmi, N., Arnawa, I. M., \& Yerizon, Y. (2019). Preparation development of learning device problem based learning model with scientific approach to improve mathematical problem solving ability. International Journal of Science and Technology Research, 8(8) pp. 522-529.

Roza, N., Arnawa, I. M., \& Yerizon. (2018). Practicality of mathematics learning tools based on discovery learning for topic sequence and series. International Journal of Science and Technology Research, 7(5) 236-241.

Sinambela, J.H., Napitupulu, E.E., Mulyono, \& Silambela, L. (2018). The Effect of Discovery Learning Model on Students Mathematical Understanding Concepts Ability of Junior High School. American Journal of Educational Research, 6(12), 1673-1677. doi: 10.12691/education-6-12-13. 